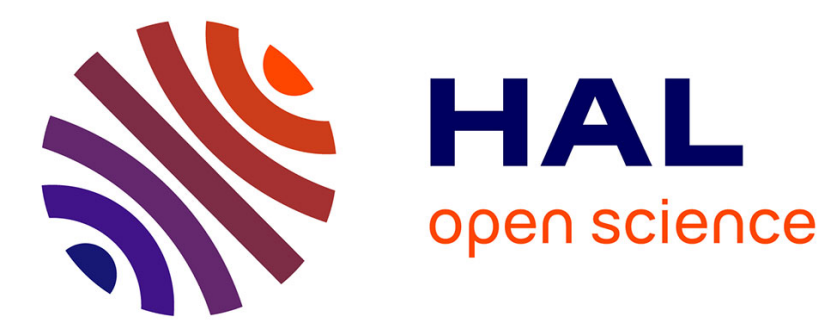

\title{
Biotelemetry based on CdTe-detectors
}

\author{
J. Bojsen, N. Rossing, O. Soeberg, S. Vadstrup
}

\section{To cite this version:}

J. Bojsen, N. Rossing, O. Soeberg, S. Vadstrup. Biotelemetry based on CdTe-detectors. Revue de Physique Appliquée, 1977, 12 (2), pp.361-363. 10.1051/rphysap:01977001202036100 . jpa-00244174

\section{HAL Id: jpa-00244174 https://hal.science/jpa-00244174}

Submitted on 1 Jan 1977

HAL is a multi-disciplinary open access archive for the deposit and dissemination of scientific research documents, whether they are published or not. The documents may come from teaching and research institutions in France or abroad, or from public or private research centers.
L'archive ouverte pluridisciplinaire HAL, est destinée au dépôt et à la diffusion de documents scientifiques de niveau recherche, publiés ou non, émanant des établissements d'enseignement et de recherche français ou étrangers, des laboratoires publics ou privés. 


\title{
BIOTELEMETRY BASED ON CdTe-DETECTORS
}

\author{
J. BOJSEN, N. ROSSING, O. SOEBERG and S. VADSTRUP
}

The Finsen Laboratory, Department of Clinical Physiology and The Radiophysical Laboratory, The Finsen Institute, 49, Strandboulevard, DK-2100 Copenhagen, Denmark.

\begin{abstract}
Small cadmium telluride radionuclide detectors (CdTe) $2-3 \mathrm{~mm}^{3}$ (developed by C. R. N. Strasbourg) have been tested with special reference to their application in biotelemetry. The temperature dependence, geometry characteristics and efficiency of the detectors have been investigated and preliminary in vivo experiments have been performed. The glomerular filtration rate was telemetrically measured by partial body counting of DTPA labeled $99 \mathrm{~m}-\mathrm{Tc}$. Bloodflow in adipose and muscle tissue was determined by local clearance studies with 133-Xe. In radiocardiographic studies with $99 \mathrm{~m}-\mathrm{Tc}$, the blood-flow of the heart can be determined. In local clearance and radiographic studies the results obtained with the CdTe-detector were compared with a single $\mathrm{NaI}(\mathrm{Tl})$ detector or a $\gamma$-camera. The CdTe-detector has been found to fulfil the requirements of a biotelemetric transducer.
\end{abstract}

1. Introduction. - The fundamental purpose of biotelemetry is to study physiological parameters in man or experimental animals with a minimum of interference. Such studies, however, are difficult to perform when radionuclide tracers are involved because their detection in general demands voluminous stationary equipment.

Small GM-detectors for detection of radionuclide tracers have been used in implanted radiotelemetric equipment [1] or externally attached to the skin for surface detection $[2,3]$.

Among several new semiconductor materials the cadmium telluride (CdTe) seems to be the most promising in the production of small transducers. We have tested the CdTe-detector $[7,8,9]$ with special reference to its use in different biotelemetry applications.

2. The detector. - The detector probe, developed by C. R. N., Strasbourg, France, consists of a CdTecrystal $\left(2-3 \mathrm{~mm}^{3}\right)$ and a preamplifier (Fig. 1). The detector material is a P-type with resistivity in the range of $10^{4}-10^{6} \Omega . \mathrm{cm}$, and it is grown by the traveling heater method, but without external chemical compen-

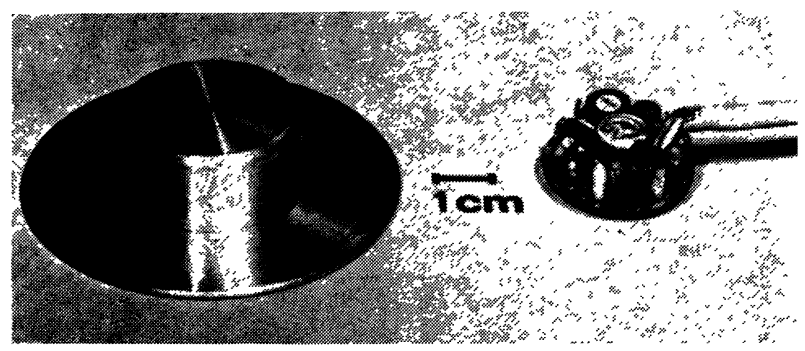

FIG. 1. - The CdTe-detector probe. The cover is shown to the left. sation. The detector crystal is directly coupled to a FET transistor, which is biased through a loading resistor. The second stage consists of a voltage amplifier, which is followed by a monostable with a triggering level adjustable to the energy scale of interest. The supply voltage of the detector is $100 \mathrm{~V} \mathrm{~d}$. c. and the preamplifier is supplied by $5.4 \mathrm{~V}(1.3 \mathrm{~mA})$ [4]. A portable $[3,5]$ or a stationary taperecorder was used for collecting of data.

3. Physical experiments. - Several requirements have to be fulfilled by a transducer in biotelemetry of radionuclide tracers. The detector must be reliable up to $42^{\circ} \mathrm{C}$. Figure 2 shows the energy spectra of a

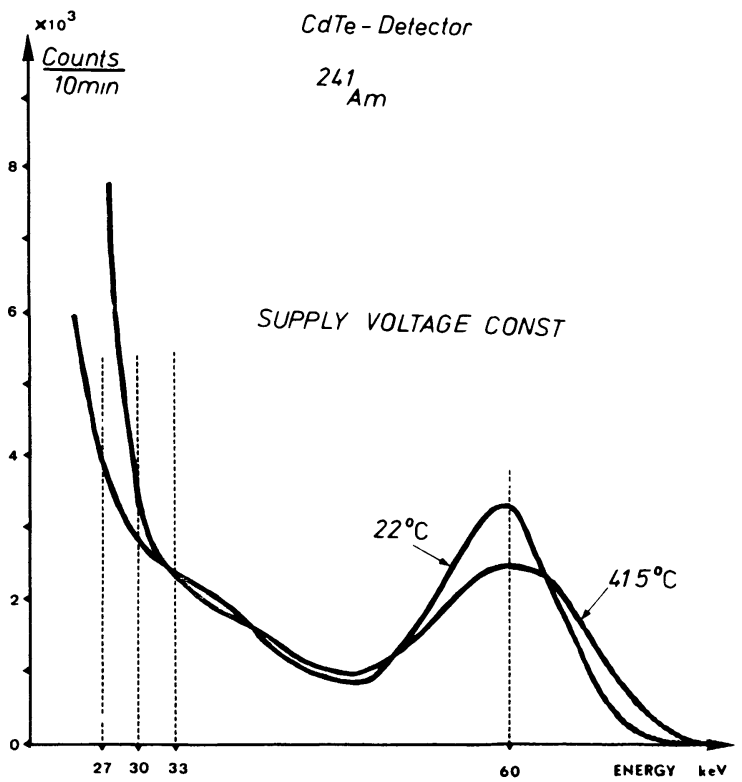

Fig. 2. - The spectra of a 241 -Am source measured at $22^{\circ} \mathrm{C}$ and $41.5^{\circ} \mathrm{C}$ 
241-Am source measured at $22^{\circ} \mathrm{C}$ and $41.5^{\circ} \mathrm{C}$ with a constant supply voltage. If the threshold level exceeds $30 \mathrm{keV}$ the integrals of the spectra at the two temperatures are equal, which means the efficiency of the $\mathrm{CdTe}$ detector probe is independent of the environmental temperature in the range of interest (Fig. 2). The leakage current of the detector is $<10 \mathrm{nA}$ at $42^{\circ} \mathrm{C}$.

Studies on point sources of $99 \mathrm{~m}-\mathrm{Tc}$ and $241-\mathrm{Am}$ in perspex show, that the detector is insensitive to transverse displacements up to $5 \mathrm{~mm}$ with a point source to detector distance of $24 \mathrm{~mm}$. Experiments with $99 \mathrm{~m}-\mathrm{Tc}$ have shown that an increase in volume of a source from $10 \mu \mathrm{l}$ to a cube of $2 \mathrm{ml}$ with an unchanged center to probe distance of $24 \mathrm{~mm}$ enhanced the count rate with about $3 \%$ (Fig. 3). With no deadtime correc-
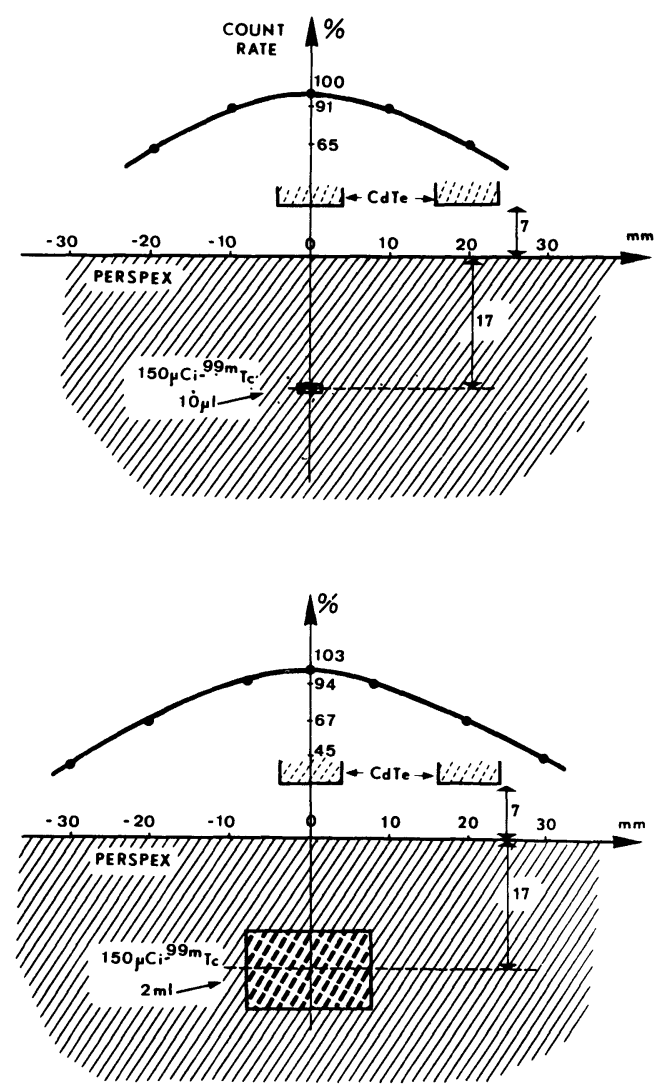

FIG. 3. - Point source study with $99 \mathrm{~m}-\mathrm{Tc}$ in perspex.

tion, the highest count rate of the probe is about $2000 \mathrm{c} / \mathrm{s}$, without any increase in pulse width from the monostable multivibrator. At energies higher than $30 \mathrm{keV}$ the background is 1-2 cpm. The sensitivity of the probe to different radionuclides uniformly distributed in water has been determined : $42-\mathrm{K}=3$, $113-\mathrm{In}=4,131-\mathrm{I}=5,99 \mathrm{~m}-\mathrm{Tc}=12 \mathrm{cpm} /(\mathrm{nCi} . \mathrm{ml})$. The sensitivity to $133-\mathrm{Xe}$ is $>12 \mathrm{cpm} /(\mathrm{nCi} . \mathrm{ml})$.

4. In vivo experiments. - In order to determine the glomerular filtration rate (GFR) in ambulant patients, we have made partial body counting studies

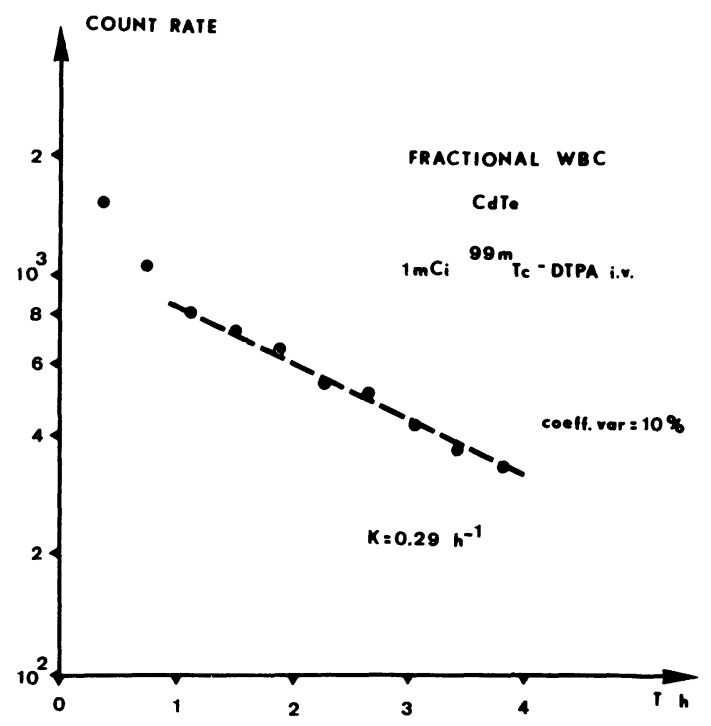

FIG. 4. - Partial body counting of DTPA-99m-Tc measured telemetrically with the CdTe-surface detector.

with DTPA-99m-Tc (RENOTEC $(R)$ ) (Fig. 4). The CdTe-detector was attached to the skin surface and the data were stored in a portable magnetic taperecorder [5]. During an investigatory period of 3-4 hours the GFR can be calculated with a coefficient of variation of approximately $10 \%$.

A number of local clearance studies has been performed in adipose and muscle tissue. In figure 5 one of the experiments is shown. 133-Xe was injected in the anterior tibial muscle, and the disappearance of Xenon was simultaneously measured with the $\mathrm{CdTe}$-detector and a 3 "-NaI(Tl)-detector. After the pressure in the cuff

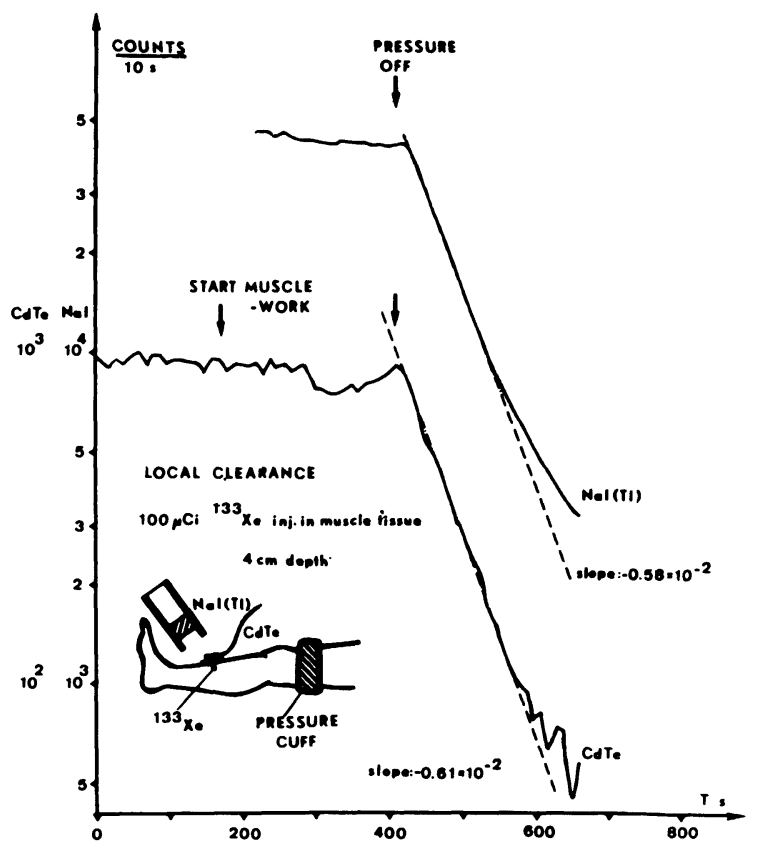

Fig. 5. - Local clearance of $133-\mathrm{Xe}$ from the anterior tibial muscle. The experimental set up is indicated. The CdTe-detector was compared with a lead collimated $\mathrm{NaI}(\mathrm{Tl})$-detector. 
was removed, the course of the curve from the CdTedetector was steeper and monoexponential a longer period of time than the curve from the $\mathrm{NaI}(\mathrm{Tl})$ detector. Due to the small tissue volume monitored by the CdTe-detector, it measures more correctly the local clearance of the Xenon depot, even without the need of lead shielding. The NaI(Tl)-detector monitors a rather big tissue volume even when restricted by lead shielding, so the radioactive Xenon is detected with high efficiency also after it has been removed from the depot by the blood.

In a similar experiment the blood flow was measured in the anterior femoral muscles during rest and ergonometry (Fig. 6). The CdTe-detector was attached to the skin surface above the injected Xenon depot.

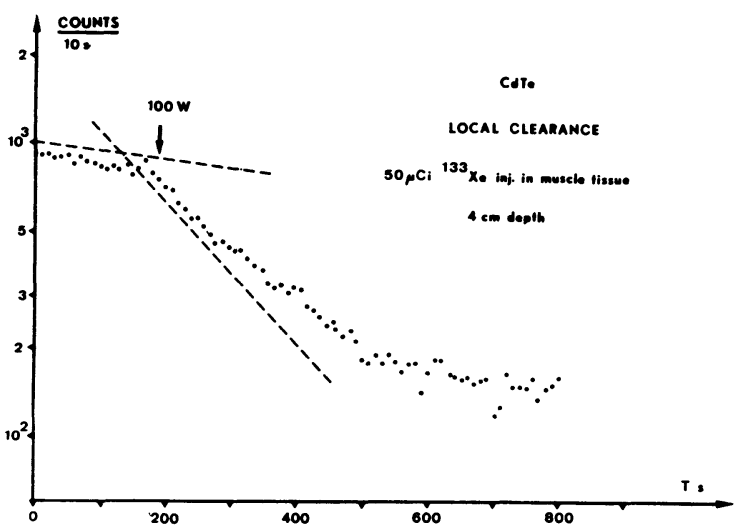

Fig. 6. - Local clearance of 133-Xe from the anterior femoral muscles during rest and ergonometry.

In cardiographic studies there is a need for measurements of the blood flow in the heart during exercise. By means of this small surface CdTe-detector attached to the skin surface over the heart, it is possible to measure the curve of a radionuclide tracer dose injected as a bolus (Fig. 7), and by proper calibration, the flow rate of the heart or cardiac output can be determined, i. e. during exercise, outside the laboratory. In radiocardiographic studies the calculation of cardiac output

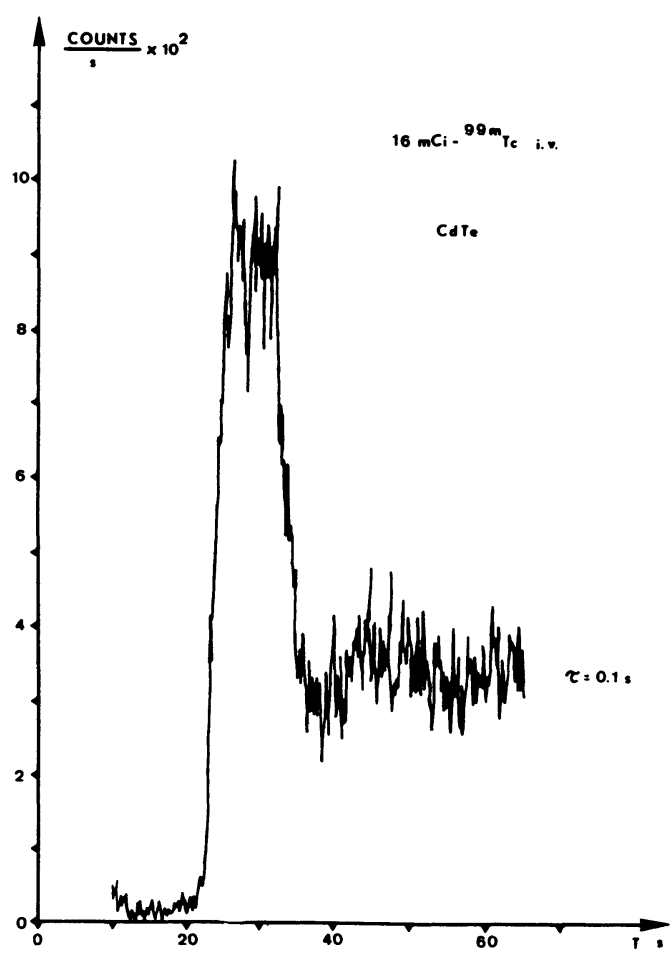

Fig. 7. - Count rate curve of an i. v. injected bolus dose of 99m-Tc. measured over the heart with the CdTe surface detector.

is normally based on $\gamma$-camera examinations. The performance of the CdTe-probe was therefore compared with that of a computerized $\gamma$-camera with digitalized regions of interest. The count rate curves simultaneously measured were compared and found alike.

5. Conclusion. - The experiments show, that the small CdTe-detector is promising as a new surface detector in nuclear medicine. Furthermore this type of detector used in external equipment in combination with f. i. a C-MOS semiconductor memory system [6] for data compression and storage, or in implantable equipment in combination with radiotransmitters, will extend the field in biotelemetry of radionuclide tracers.

\section{References}

[1] Bojsen, J., Wallevik, K., Int. J. Appl. Radiat. Isot. 23 (1972) 505.

[2] Bojsen, J., Vadstrup, S., Int. J. Appl. Radiat. Isot. 25 (1974) 161.

[3] Bojsen, J., Vadstrup, S., Proc. 2nd ISPRA Nucl. Electronics Symp. Stresa, Italy, 205, 1975 (EUR 5370e).

[4] Bojsen, J., Vadstrup, S., Siffert, P., Regal, R., Cornet, A., Proc. 3rd Int. Symp. on Biotelemetry, Asilomar, California, May 1976, Academic Press (in press).

[5] Bojsen, J., Vadstrup, S., Am. J. Appl. Physiol. 41 (1976) 416.
[6] Bojsen, J., Proc. 3rd Int. Symp. on Biotelemetry, Asilomar, California, May 1976, Academic Press (In press).

[7] Cornet, A., Regal, R., PonPon, J. P. et al., 2nd ISPRA nuclear electronics Symposium. Stresa, Italy, 169, 1975 (EUR 5370e).

[8] Siffert, P., Ponpon, J. P., Cornet, A., Onde électr. 55 (1975) 281.

[9] Siffert, P., Berger, R., Scharager, C. et al., Trans. Nucl. Sci. NS-23 (1976) 159. 